\title{
Kyiv Metropolia and Moscow Diplomacy: an Ottoman Viewpoint
}

\author{
Oles Kulchynskyy \\ Institute of Turkic Studies at Istanbul University, Istanbul, Turkey \\ kulchynskyy@gmail.com \\ Ömer Kul \\ Institute of Turkic Studies at Istanbul University, Istanbul, Turkey \\ kulomer@hotmail.com
}

\begin{abstract}
The Muscovite legation to the Ottoman Empire in 1686 enabled the final stage of annexation of the Kyiv Metropolia by the Patriarchate of Moscow at the end of the 17th century. However, previously ignored Ottoman sources (the official register of Ottoman affairs in 1686-1687, the History of Silahdar chronicle, and a fragment of the European chronicle Relazione di Constantinopoli) contradict the Russian narrative. This casts doubt on the veracity of the Muscovite diplomatic mission in 1686 and, therefore, the process of separation of the Kyiv Metropolia from the Patriarchate of Constantinople.
\end{abstract}

\section{Keywords}

Kyiv Metropolia - Ottoman Empire -Patriarchate of Moscow - Patriarchate of Constantinople - Ottoman historical sources.

\section{Introduction}

In the late seventeenth century, the Muscovite State, having annexed LeftBank Ukraine, began its expansion into the North Black Sea region. Its first war against the Ottoman Empire took place in 1676-1681 but the Treaty of Bakhchisaray in 1681 did not bring any territorial gains. ${ }^{1}$ Five years later, the Tsardom

1 С.М. Соловьев [S.M. Solovyov], История России с древнейших времен [History of Russia 
of Muscovy joined the Holy League, an anti-Ottoman alliance of the Holy Roman Empire, the Venetian Republic, and the Polish-Lithuanian Commonwealth. In 1695, the Muscovites took Turkish and Crimean fortresses on the Dnieper, and, in 1696, gained access to the Black Sea after seizing the Azak (Azov) fortress. ${ }^{2}$ At the same time, the Ottoman State after a war against the Holy League in 1683-1699, lost its territories in Hungary, Transylvania, Podolia, and parts of West-bank Ukraine. ${ }^{3}$

In this context, it's obvious that in 1686 the Moscow Patriarchate annexed the Kyiv Metropolia, previously subject to the Constantinople Patriarchate, in line with the expansionist strategies of the Muscovy Tsardom in the Black Sea region. The subjugation of the Metropolia to the Russian Church broke off the close ecclesiastical relations between Ukraine and the Ottoman Empire. ${ }^{4}$

from the Earliest Times], book 3, vol. XIV, St. Petersburg, 1896, pp. 823-856; A.N. Kurat [A.N. Kurat], Rusya Tarihi [History of Russia], Ankara, 2014, pp. 250-252.

2 Соловьев, История, book 3, vol. xIv, pp. 980-986, 1145-116o; Kurat, Rusya Tarihi, pp. 252, $272-283$.

3 İ.H. Uzunçarşılı [I.H. Uzuncharshyly], Osmanlı Tarihi [Ottoman History], tome III, vol. 2, Ankara, 2011, pp. 532-536.

4 See: М.С. Грушевський [M.S. Hrushevsky], Iсторія України-Pуси [History of Ukraine-Rus'], tome IX, book 1, New-York, 1957, pp. 48, 119-123, 132, 217, 293, 298-299; Виталий Эйнгорн [Vitalii Einhorn], О сношениях малороссийского духовенства с московским правительством в иарствование Алексея Михайловича [The Relations Between the Little Russian Clergy and the Moscow Government at the Time of Aleksei Mikhailovich, Moscow 1890, pp. 93-94, 138, 141, 146, 150, 153, 158-16o, 198, 204, 208-209, 592-596, 599-6o2; К.В. Харлампович [K.V. Kharlampovich], Малороссийское влияние на великорусскую иерковную жизнь, [Small-Russian influence on Great-Russia Church Life], vol. I, Kazan 1914, pp. 144-145, 162, 175-176, 178-179, 187-189, 194-195, 207-209, 211; С. Терновский, “Исследование о подчинении Киевской митрополии Московскому патриархату" [S. Ternovskij, "Study on the Submission of the Kyiv Metropolia to the Moscow Patriarchate"], Архив Юго-Западной России [Archives of Southwestern Russia], T.V. Kiyev, 1872, pp. 64-64, 68, 127-128; Вера Ченцова [Vera Chentsova], Восточная Церковь и Россия после Переяславской Рады. 1654-1658. Документы [The Eastern Church and Russia after the Pereyaslav Council. 1654-1658. The Documents], Moscow, 2004; Б.Н. Флоря, “Константинопольский патриарх Парфений II и гетман Богдан Хмельницкий” [B.N. Florya, "Patriarch Parthenios II and Hetman Bogdan Khmel'nickij"], Мобхоßí. Проблемы византийской и новогреческой филологии [Moscovia. Problems of Byzantine and Modern Greek Philology], Т. 1, Moscow, 2001, pp. 443-447; Б.Н. Флоря, "Митрополит Иосиф (Тукальский) и судьбы православия в Восточной Европе в XVII веке” [B.N. Florya, "Metropolitan Josef (Tukalskiy) and Fates of Orthodoxy in Eastern Europe in the XVII century"], Вестник иерковной истории [Herald of Church History], 1-2 (134) (2009), p. 123-147; Я. Дашкевич, “Протурецька орієнтація XVI-XVII ст. в Україні та міжнародні відносини” [Y. Dashkevych, "Pro-Turkish Orientation in Ukraine in the XVI-XviI Centuries and International Affairs"], Хроніка-20оо [Chronicle-20oo], 1 (95) (2014), pp. 4-14; Ю. Луняк, "Перебування Юрія Хмельницького у турецькому полоні за свідченнями французького дипломата Де ла Круа” [Y. Lunyak, "Yuriy Khmelnytsky in Ottoman Captivity According to 
In this situation, it would be logical to study the annexation of the Kyiv Metropolia from the perspective of the Ottoman, Ukrainian, and Russian relations, using both Turkish and Western European documentation. These documents, however, remain sorely under-researched. ${ }^{5}$ Still, plenty of Turkish archive documents and chronicles of that era could shed light on important events in the church life of the Cossack Hetmanate and the involvement of Ottoman authorities in them. This possibility is enabled by the official documents of the Divan or Council of the Ottoman Empire, where all orders concerning different aspects of the state life were scrupulously written down. Whereas the separation of the Kyiv Metropoly from the Ecumenical Patriarchate was implemented due to the negotiation of the Moscow legation to Edirne in 1686, the information about it as an element of the mission at the court of the Ottoman sultan had to be definitely recorded in the official registers of the

the Evidences of French Diplomat De la Croix"], Січеславський альманах [Almanac of Sicheslav], 6 (2011), pp. 5-16.

5 Seе О. Шевченко, "Про підпорядкування Київської митрополії Московському патріархатові наприкінці XVıг ст." [O. Shevchenko, "On the Subjugation of the Kyiv Metropolia to the Moscow Patriarchate"], Украӥнський історичний журнал [Ukrainian Historical Journal], 1 (1994), pp. 54-61; I. Власовський [I. Vlasovsky], Нарис історіїУкраӥнської православної церкви [Outline of the History of the Ukrainian Orthodox Church], 2 vol., NewYork-Kyiv, 1990, vol. II; Р. Єринюк, “Підпорядкування Київської митрополії Московській патріархії 1685-86" [R. Yerynyuk, "The Subjugation of the Kyiv Metropolia to the Moscow Patriarchate 1685-86], Ювілейний збірник праць наукового конгресу у ооо-ліття хрищення Руси-Украӥни [Jubilee Collection of Works of the Scientific Congress on the 1oooth Anniversary of Rus'-Ukraine Baptism], Munich, 1988/1989, pp. 732-750; I. Огієнко [I. Ohiyenko], Приеднання Церкви Украӥнськоїдо Московської в 1686 p. [The Annехаtion of the Ukrainian Church by the Moscow Church in 1686], Winnipeg, 1948; idem, Українська церква: Нариси з історії української православної церкви [The Ukrainian Church: Outline History of the Ukrainian Orthodox Church], Winnipeg, 1982; idem, Ідеологія украӥнської церкви [The Ideology of the Ukrainian Church], Chelm, 1944; Б. Крупницький [B. Krupnytsky], Гетьмани іправославна иерква в Українській державі XVII-XVIII cm. [The Hetmans and the Orthodox Church in the Ukrainian State of the XVII-XVIII centuries], New-York, 1954; Г. Удод [H. Udod], Приеднання української церкви до Московського патріархату 1686 [The Annexation of the Ukrainian Church by the Moscow Patriarchate in 1686], Winnipeg, 1972; Zenon E. Kohut, "The Problem of Ukrainian Orthodox Church Autonomy in the Hetmanate (1654-1780s)", Harvard Ukrainian Studies, vol. 14, 3-4 (1990), pp. 364-376; B.М. Лурье [B. Lourié], Русское православие между Киевоми Москвой:Очеркистории русской православнойтрадииии между ХV иХХвеками [Russian Orthodoxy between Kyiv and Moscow: Outline History of the Russian Orthodox Tradition between the XV and XX Century], Moscow, 2010, pp.173-227; Konstantinos Vetochnikov, "La "concession" de la métropole de Kiev au patriarche de Moscou en 1686: Analyse canonique", 23rd International Congress of Byzantine Studies, 22-27 August, 2016. Abstracts, Belgrade, 2016, pp. 37-41; В.Г. Ченцова, “Синодальное решение 1686 г. о Киевской митрополии” [V.G. Chentsova, "The Synodical Decision about the Kyiv Metropolia in 1686"], Древняя Русь. Вопросы медиевистики [Ancient Rus: Questions of the Medieval Studies], 2 (68) (2017), pp. 89-110. 
Divan. In return, the absence of such information in official records must serve as an evidence of unclear circumstances under which the subjugation of the Kyiv Metropolia to Moscow occurred as well as the distortion of the relevant narration that is known today. Remarkably, the official records of the Divan dating exactly to 1686 have survived in the form of şikayet defterleri (Ottoman Turkish for Registers of Complaints). These Ottoman documents were used in this research to elucidate the circumstances under which the Kyiv Metropolia was separated from the Patriarchate of Constantinople. The research is focused on the Muscovite mission to Edirne in 1686 which implemented the concession of the Kyiv Metropolia to Moscow.

The transfer of the Kyiv Metropolia was carried out in June 1686, when Patriarch Dionysius IV, according to the decision of the Council, bestowed upon the Ukrainian Hetman Ivan Samoylovych and his subjects the charters that sanctioned the release of the Kyiv Metropoly from the dominion of the Ecumenical Patriarchate and its subjugation to Moscow. The Council also accepted Gedeon Chetvertynsky as the Metropolitan of Kyiv, in spite of his illegal investiture by Joachim, the Patriarch of Moscow. ${ }^{6}$

However, these events are known from a sharply limited amount of primary sources. ${ }^{7}$ The principal source is the handwritten collection known as Ikona, or a Description of the Events Transpired in Different Times and Years in the Great Catholic [= Counciliar] Church of the Holy Rus' and in All Northern Countries of the Patriarchal Throne. In 1872, its documents were published in Vol. 5 of the "Archives of Southwestern Russia" (ASWR). ${ }^{8}$ This edition also includes a Study on the Submission of the Kyiv Metropolia to the Moscow Patriarchate by S.

6 Терновский, “Исследование о подчинении”, pp. 115-129, 142-143.

7 Шевченко, “Про підпорядкування". Also see “Предисловие” ["Preface”], Архив ЮгоЗападной России, издаваемьй Временною комиссиею для разбора древних актов, Высочайше утвержденною при Киевском военном, Подольском и Вольнском генералгубернаторе [Archives of Southwestern Russia, Published by the Temporary Commission for the Analysis of the Ancient Acts, Highly Appointed Under the Kyiv Military, Podillya and Volyn Governor General], vol. v, Kyiv, 1872, pp. I-XI.

8 “Акты, относящиеся к делу о подчинении Киевской митрополии Московскому патриархату (1620-1694 гг.)" ["The Acts Relating to the Case of the Submission of the Kyiv Metropolia to the Moscow Patriarchate (1620-1694)"], Архив Юго-Западной России, издаваемый Временною комиссиею для разбора древних актов, Высочайше утвержденноюприКиевском военном, ПодольскомиВольнскомгенерал-губернаторе. [Archives of Southwestern Russia, Published by the Temporary Commission for the Analysis 


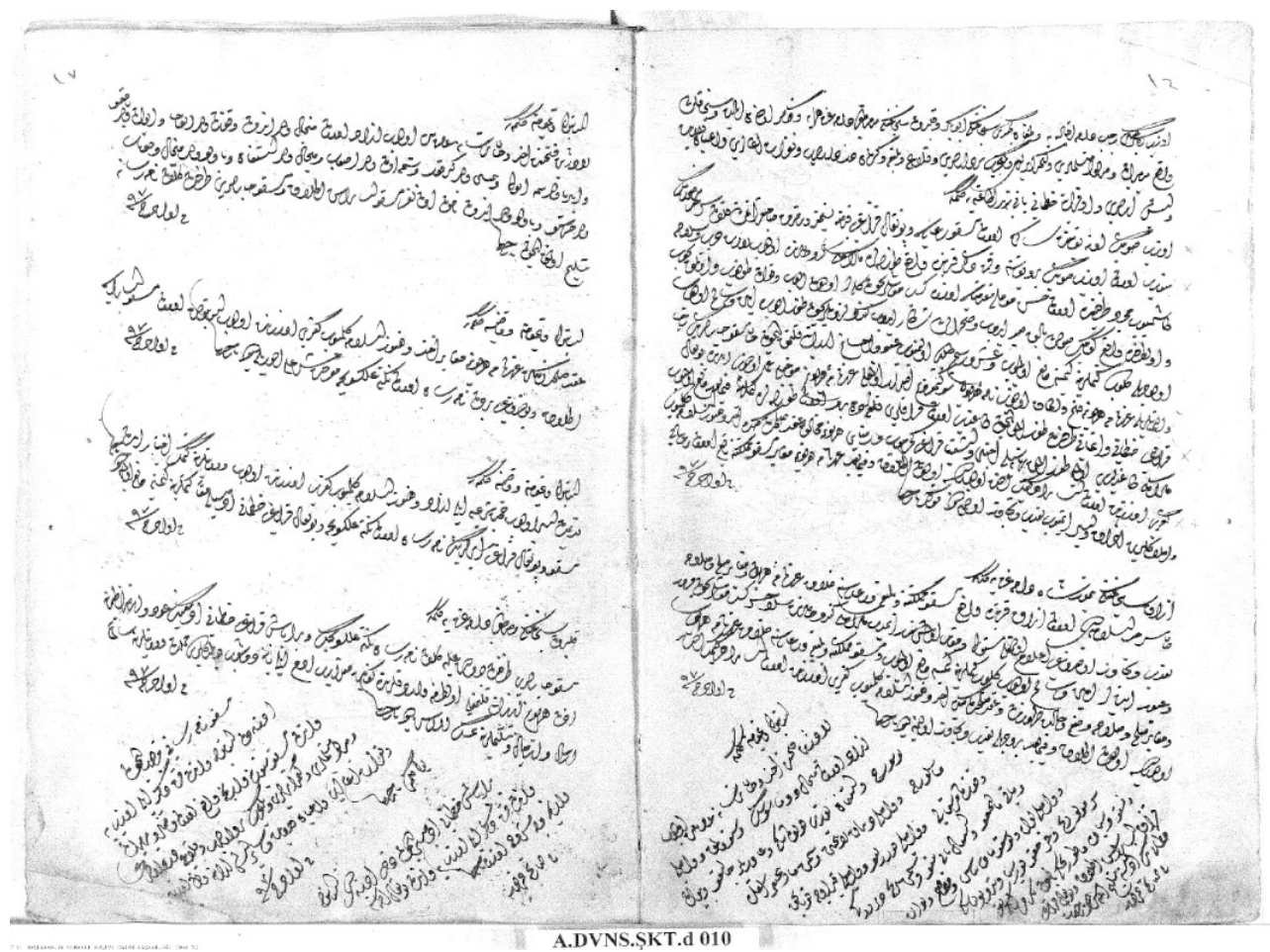

FIGURE 1 Şikayet Defteri 1097/1098 [Register of Complaints 1097/1098], T.C. Başbakanlık Osmanlı Milli Arşivi [Turkish Republic, the Prime Minister's Ottoman Archive], Istanbul, pp. 16-17.

Ternovskij, Professor of Kazan Theological Academy. Apart from the Ikona... documents, he also used in his research the Vol. 14 of S.M. Solovyov's History of Russia"9, who, in his turn, used the Collection No. 4 of the Moscow Patriarchate Synodal Library. ${ }^{10}$

Of similar significance is Nikolay Fëdorovich Kapterev's work The Relations of the Patriarch of Jerusalem Dositheos with the Russian Government (1669-1707). ${ }^{11}$ Although this study is rather brief and mostly derivative of S.M. Solovyov and $\mathrm{S}$. Ternovskij, it gives some precious insights concerning the dating of Moscow

of the Ancient Acts, Highly Appointed Under the Kyiv Military, Podillya and Volyn Governor General], vol. v, Kyiv, 1872.

9 Терновский, “Исследование о подчинении”, pp. 141-145.

10 Соловьев, История, book 3, vol. XIV, p. 1002.

11 Н.Ф. Каптерев [N.F. Kapterev], Сношения Иерусалимского Патриарха Досифея с русским правительством (1669-1707) [The Relations of the Jerusalem Patriarch Dositheos with the Russian Government (1669-1707)], Moscow, 1891. 
legation's activity. Kapterev used registers No. 20, 21, 25 and 26 of Turetskiye Stateynyie Spiski ("Turkish State Reports"), which provide detailed information on the activity of the Muscovite legation. ${ }^{12}$ S.M. Solovyov also used these registers as a source of his narrative, although he does not give any direct reference to them. ${ }^{13}$ It seems likely that S. Ternovskij used them as well in his Study on the Submission of the Kyiv Metropolia to the Moscow Patriarchate.

According to N. Rogojin's The Ottoman State in the Reports of Russian Diplomats (XVI-XIX Centuries), the "Turkish State Reports" for 1685-1686 have not been studied yet. In reality, they form part of the documents of the Posolskiy Prikaz (Muscovite foreign affairs offers in the 16th - early 18th centuries) as a part of Russian State Archives. ${ }^{14}$ Only in 2017 did Vera Chentsova reveal some of their unknown fragments to their public; however, they are still not published in their entirety. ${ }^{15}$ Thus, until now, we only have parts of the $1685^{-1686}$ "Turkish State Reports", mostly as paraphrased by 19th-century historians, at our disposal.

Therefore, the 19th-century studies focusing on events of 1686 are based on three primary sources: Ikona..., the collection No. 4 of the Synodal Library, and extracts from the "Turkish State Reports" for years 1685-1686, known to us only as narrated by S.M. Solovyov, S. Ternovskij and N.F. Kapterev.

The story of the Russian legation to Edirne in 1686, led by the Russian podyachiy ${ }^{16}$ Nikita Alekseyev, forms the principal narrative of aforementioned studies. According to them, in November 1685, after the illegal investiture of Gedeon Chetvertynsky as the Metropolitan of Kyiv conducted by Patriarch Joachim, Alekseyev was sent from Moscow to Edirne. He was tasked with delivering charters from the Tsars and Joachim to the Patriarch of Constantinople James, requesting to accept the new rank of Chetvertynsky and to transfer his primacy over the Metropolia of Kyiv to the Moscow Patriarch. On his way to Edirne, the podyachiy was joined by Ivan Lysytsya, a Cossack colonel and legate of the Ukrainian Hetman Ivan Samoylovych. In 1686, the legates reached Edirne,

\footnotetext{
12 Ibid., pp. 73-85.

13 Соловьев, История, book 3, vol. XIV, pp. 997-1002.

14 N. Rogozhın, "Rus Diplomatların Raporlarında Osmanlı Devleti (Xvi-Xıx Yüzyıllar)" [N. Rogozhin, "The Ottoman State in the Reports of the Russian Diplomats" (xvI-XIX Centuries)"], Osmanlı [Ottoman], vol. I (1999), pp. 527-536.

Ченцова, “Синодальное решение". Vera Chentsova also presented some fragments of "Turkish State Reports" concerning Moscow legation to Edirne in 1686 on the International seminar Le patriarcat de Constantinople et le rattachement de la métropole de Kiev à Moscou en 1686 : nouveaux témoignages d'archives et recherche de definitions, held in Kyiv in February 2017. The publication of her paper is forthcoming.

16 Podyachiy is an administrative post in Posolskiy Prikaz and other government offices of the Tsardom of Muscovy.
} 
then-residence of the Ottoman Sultan Mehmed IV. ${ }^{17}$ S.M. Solovyov notices that a part of their mission was to protest against the Ottomans luring the Leftbank population (subjects of the Tsardom of Muscovy) to the Right-bank Ukraine, an Ottoman territory. ${ }^{18}$

In Edirne, Alekseyev, trying to resolve the issue of the Metropolia in secret from the Porte, met with Dositheos II Notaras, Patriarch of Jerusalem. The legate asked Dositheos to convince the Patriarch of Constantinople to transfer the Metropolia of Kyiv to Moscow, with Dositheos refusing. ${ }^{19}$ Meanwhile, in March 1686, Dionysius IV replaced his predecessor James on patriarchal throne ${ }^{20}$; Alekseyev immediately started negotiating directly with him. ${ }^{21}$ With little progress in the negotiations with the patriarchs, the podyachiy appealed to the Ottoman sadrazam (grand vizier), and, in spite of the secrecy of the issue, asked him to influence the patriarchs. Accordingly to S. Ternovskij and S.M. Solovyov, the grand vizier acquiesced, and Patriarch Dositheos changed his position in exchange for 200 red (golden) coins. $^{22}$

Later the legate met with Dionysius IV, who came to the sultan's Edirne residence to obtain an official recognition of his rights to the patriarchal throne. Patriarch promised to transfer the Metropolia to Moscow after returning to Istanbul and obtaining the consent of the Council. In June, Alekseyev received charters from the Patriarch, authorizing of the transfer, and gave him, on behalf of the Muscovite Tsar, 200 golden coins and $3 \operatorname{sorok}^{23}$ of sable pelts. Afterwards, the legate departed to Moscow. ${ }^{24}$

A widespread view maintains that the grand vizier acquiesced to resolve the church issue while trying to preserve the 1681 Bakhchysarai Peace Treaty. ${ }^{25}$ By that time, the Ottomans had been fighting the Holy League for three years and needed to avoid a new menace from the North. However, immediately after the annexation of the Metropolia, Muscovite troops invaded the Crimean Khanate, a vassal of the Ottoman Empire. ${ }^{26}$ Alekseyev's mission itself transpired

\footnotetext{
17 Терновский, “Исследование о подчинении”, pp. 115-134.

18 Соловьев, История, book 3, vol. XIV, p. 1000.

19 Терновский, “Исследование о подчинении”, pp. 134-140; Соловьев, История, book 3, vol. XIV, pp.1000-1001.

20 Э.П.Г., “Дионисий IV Серогланис" [E.P.G., "Dionysius IV Seroglanis”], Православная Энииклопедия [Orthodox Encyclopedia], T. XV, Moscow, 2007, pp. 305-307. Терновский, “Исследование о подчинении”, p. 140. Ibid., pp.141-142; Соловьев, История, book 3, vol. XIV, pp. 1001-1002. Old Russian unit of measurement used in fur trade: a bundle of forty pelts. Терновский, “Исследование о подчинении”, pp. 142-147. Ibid., pp. 141, 145; Соловьев, История, book 3, vol. XIV, p. 1002. See footnote 5 . Соловьев, История, book 3, vol. XIV, p. 1004.
} 
while Muscovy, in secret from the Ottomans, joined the Holy League by virtue of ratifying the "Eternal Peace" with Poland-Lithuania on April 21, 1686. ${ }^{27}$

The claim that the Ottoman authorities, faced with imminent military danger, abandoned their leverage on Ukrainian ecclesiastical and political matters, seems unlikely, especially given the Russian description of Alekseyev's legation. According to this description, the legate, in spite of the Tsar's and his own will to resolve the problem in secret from the Porte, achieved his goal only thanks to Turkish involvement. The Ottoman sources used in this study critically reinforce the doubts regarding the governing narrative of the 1686 events. ${ }^{28}$

\section{Evidence of the Ottoman Sources}

The mühimme defterleri (primary registers of the Divan) from 1686, containing the records of all rulings and decisions of the Ottomans concerning their inner and foreign policy, are missing in the Ottoman Archives in Istanbul, probably a casualty of Istanbul's frequent fires in the XVII-XVIII centuries. ${ }^{29}$ However, starting in 1649, the secretaries of the Divan also provided important "registers of complaints" (şikayet defterleri), keeping account of various petitions to the central Ottoman authorities and sultan's orders given pursuant to the decisions of the Divan on various complaints..$^{30}$ One of such registers, according to the Islamic calendar, was written from the beginning of Jumada al-Akhira ${ }^{31}$

$27 \quad$ Ibid., pp. 983-986.

28 B. Lourié and K. Vetoshnikov have already claimed that the Russian narratives regarding the transfer of the Kyiv Metropolia are self-contradictory, pointing to the fact that the charters of the Ecumenical Patriarch don't mention the transfer of the Metropolia and casting its very factual veracity into doubt. Seе В.М. Лурье, Русское православие, pp. 173227; Konstantinos Vetochnikov, "La «concession». With this paper still in preparation, Vera Chentsova published the newly discovered Greek copies of two 1686 charters of Dionysius IV and the Council concerning the Metropolia of Kyiv, their content demonstrating even more clearly that the Patriarchate of Constantinople did not forfeit or transfer its canonical territories to Moscow. Seе.: В.Г. Ченцова, “Синодальное решение 1686 г. о Киевской Митрполии" [V.G. Tchentsova, "The Synodal Decision of 1686 about the Metropolia of Kyiv"], Древняя Русь. Вопросы Медиевистики [Ancient Rus. Questions of the Medieval Studies], № 2 (68), Moscow, 2017, pp. 89-92.

29 See Midhat Sertoğlu [Midhat Sertoolu], Muhteva Bakımından Başvekalet Arşivi [The Archive of the Prime Ministry from the Point of View of its Content], Ankara, 1955.

30 Aktaş Necati, "Atik Şikâyet Defteri" [Aktash Nedjati, "The Ancient Register of Complaints"], Türk Diyanet Vakfi Islam Ansiklopedisi [The Turkish Religious Affairs Foundation's Islamic Encyclopedia], vol. IV, Istanbul, 1991, p.68.

$31 \quad$ The sixth month of the Islamic lunar calendar (Ottoman Turkish). 
1097 / end of April 1686 until 22 Zul Hijjah ${ }^{32} 1098$ / 29 October 1687 (hereinafter - Şikayet defteri, 1097-1098). This register was written down during a difficult period of the war against the Holy League, and its records include much important evidence that would have also been included in the primary mühimme registers. ${ }^{33}$ The pages of Sikayet defteri, 1097-1098 contain new information regarding the Muscovite mission in Turkey in 1686 (see Appendix N1).

The official Ottoman document, unlike Russian sources, makes no mention of the church issue, focusing on other aspects of the mission introduced in its two pages. The sultan's rescripts ordain the following: repeat one of the conditions of the Bakhchysarai Peace Treaty which guaranteed to inhabitants of the Left-bank Ukraine the right of free movement to Ottoman's domains with the aim of fishing, salt mining and hunting; ${ }^{34}$ enable the liberation Ukrainian and Russian slaves from their servitude in Istanbul's admiralty; and sanction the return of the legates. ${ }^{35}$

Furthermore the sultan's rescripts order to return the "person" that had previously arrived to the sultan's court from the Hetman of the "Potkal Cossacks" (in other place the "Barabash Cossacks") to the Potkal Island, i.e. Zaporijja. ${ }^{36}$ According to the rescripts, this duty was to be fulfilled by the Ottoman administrators, including one "Yani, the Hetman of Ukrayna". His name is the Greek form of the Ukrainian name Ivan, and this alteration appears entirely natural in the Greek-speaking circles of the Patriarchate of Constantinople and the dragomans of the Sublime Porte.

In the XviIth century, it was Ivan Dragynych, the Acting Hetman of the Right-bank Ukraine, who went down in history under the name Yani. In 1684,

32 The last month of the Islamic lunar calendar (Ottoman Turkish).

33 M. Demir [M. Demir], 1686-1687 (h. 1097-1098) Tarihli Atik Şikâyet Defterinin Transkripsiyonu ve Değerlendirilmesi, Yayınlanmamış Yüksek Lisans Tezi. İstanbul Üniversitesi, Sosyal Bilimler Enstitüsü [The Transcription and Evaluation of the Ancient Register of Complaints dated to 1686-1687 (1097-1098 Years of the Hijra), Unpublished Master's Thesis. University of Istanbul, Institute of Social Sciences], Istanbul, 2010, p. III.

34 Cf. Статейный список стольника Василия Тяпкина и дьяка Никиты Зотова посольства в Крым в 1680 г. для заключения Бахчисарайского договора [The State Reports of the Legation to Crimea in 168 of Stolnic (Pantler) Vasiliy Tyapkin and Deacon Nikita Zotov for the Conclusion of the Bakhchysarai Peace Treaty], Odessa, 1850, pp. 143-144.

35 See: Appendix 1.

36 There are a lot of explanations on the Ottoman names of the Ukrainian Cossacks; it is obvious, however, that in Şikayet defteri, 1097-1098 "Barabash" and "Potkal Cossacks" are one and the same. Evliya Chelebi's Seyahatname mentions that the Ottomans called the main Cossack territory, the Zaporijska Sich, "the land ("island" in the register) of Butkaly / Potkaly". Therefore, the Ottoman register tells about Zaporijska Sich. Sеe Эвлия Челеби [Evliya Chelebi], Книга путешествия. Земли Молдавии и Украины [The Book of Travels. Lands of Moldavia and Ukraine], book 1, Moscow, 1961, pp. 209-214. 
however, he disappears from the documentation of the Ottoman-controlled Right-bank Ukraine. ${ }^{37}$ Therefore, it is plausible that the fragment of Şikayet defteri, 1097-1098 refers to Ivan Samoylovych, the Hetman of "Barabash" and "Potkal Cossacks", who had sent his own legate along with Alekseyev.

At the same time, precisely in 1686, Samoylovych objected to the "Eternal Peace" between Moscow and Warsaw and the Tsar's military campaign against Crimea. His son Grigoriy led the Cossack colonels who rebelled against Muscovy's anti-Turkish policy. ${ }^{38}$ Hetman's secret diplomacy with the Crimean Khanate is confirmed as well. ${ }^{39}$

On the other hand, it seems illogical that the Ottomans would issue orders to a Hetman who had sent a legate to them. The sultan's directive, consequently, could be purely nominal, used to signify the desire of the Sublime Port to see the Hetman of the Left-bank Ukraine as a vassal. Şikayet defteri, 1097-1098 can bear evidence to previously unknown contacts between the Ottomans and Left-bank Cossack leaders, thus once again contradicting the Russian sources regarding the subjugation of the Metropolia.

At the same time, an Ottoman chronicle known as the History of Silahdar contradicts the Russian narratives even stronger. The chronicle was written by Silahdar Findıklı Mehmed Ağa (1658-1726/1727), ${ }^{40}$ who described the 1686 events as a direct witness. ${ }^{41}$ The first part of his chronicle, Zeyl-i Fezleke, a chap-

T. Чухліб [T. Chuhlib], Козаки і монархи [Cossacks and Monarchs], Kyiv, 2009, pp. 306312.

38 Seе В. Станіславський, “Статті гетьмана Івана Самойловича щодо “Вічного миру” [V. Stanislavsky, "Hetman Ivan Samoylovych's Registers Concerning “Eternal Peace”], Украӥна в Центрально-Східній Європі [Ukraine in Central Eastern Europe], N 1 (2000), pp. 348385; O. Ohloblyn, Hetman Ivan Mazepa and His Epoch, New-York, 1960, pp. 23-31. Чухліб, Козаки імонархи, р. 361.

40 Mehmed Aga Silahdar (1658-1726/1727) served in military administrative position in the Ottoman court. After Ahmed III rose to power in 1703, he served for less than a year as a on a silahdar ("sword-bearer"), one of two main valets of the sultan who accompanied their master everywhere (hence his moniker Silahdar under which he went down into history). After his death, his work was forgotten due to contradicting the canons of official prose and published only in 1928. The History of Silahdar is a conventional name for two different books. The first of them is Zeyl-i Fezleke ("Continuation of the Summary"), covering events from 1654 to 1695 and written as a continuation of Katib Chelebi's work Fezleketü't Tevarih ("The Summary of History"). The second, Nusretname ("Book of Victory", covers the period between 1695 and 1721. See M. Karaçay Türkal, "Silahdar Fındıklılı Mehmed Ağa'nın Hayatı ve Eserleri (1658 / 1726-27)" [M. Karachay Turkal, "The Life and Works of Mehmed Aga Silahdar of Fyndykly"] Mavi Atlas. Gşü Edebiyat Fakültesi Dergisi [Blue Atlas. Journal of the Faculty of Literature of Gumushhane University], 1 (2013), pp. 2850.

41 Türkal, "Silahdar". 
ter named "The visit of the Moscow legate" depicts Alekseyev's audience at the court of Mehmed IV in A.H. ${ }^{42} 1097$ (CE. 1686). Silahdar writes:

On the twentieth day (14.04.1686) of the aforementioned month (Jumada al-awwal ${ }^{43}$ ), on Sunday, the Muscovite legate was invited to the Divan of the Padishah and given the audience. Having been granted a hilat [a robe of honor] in the Chamber of Petitions [Ottoman Turkish Arz Odası], he prostrated his face on the ground and told the supplication contained in his letter: may our ${ }^{44}$ friendship with the High State is appropriate as before, and may merchants from both side come and go safely, and may the [Tsar's] rayah $^{45}$ not be subjected to violence, may the Tatar nation be under control, may our legate without delay be sent [back], and may forty Muscovites and Cossacks by their names held in the Tersane-i Amire ${ }^{46}$ be released without ransom and payment, may the salt deposit on the Crimean border be given to us, and may our legate be sent to Istanbul, may he come to the church near the Fener's gate and pray for us after he declares to our benefactor, Patriarch-efendi ${ }^{47}$, our servitude as soon as he meets him. ${ }^{48}$ His Majesty the Padishah replied smiling: "Do you see what my efendi little/drunk ${ }^{49}$ kafir (infidel) wrote?" My protector agreed to all supplications, he only ordered them to give up the desire for the salt deposit; should the need arise, they may come without bands and the

After Hijra, Lat. Anno Hegirae.

The fifth month of the Islamic lunar calendar.

The chronicler uses the first-person plural to paraphrase the words of the Muscovite legate.

Rayah or reaya is a term for the members of the tax-paying lower class of the Ottoman society; here it is used concerning the same class of the Tsardom of Muscovy.

The main base and naval shipyard of the Ottoman Empire located in Istanbul on the Golden Horn.

Efendi - senior, mister, lord, patron (Turkish)

Fener (Greek Фavápl-«lantern») - a neighborhood in the European part of Istanbul, residence of the Constantinople Patriarch is situated since the late Xvith century, often used a shorthand for the Ecumenical Patriarchate.

The 1928 edition of the History of Silahdar (in Arabic-Ottoman script) uses the word سيكـارى (sikâri), which means "little", as the attributive of the next word "kâfir" (infidel). But Nazire Karachay Turkal in his transliterated text based on the comparison of original copies uses the word "sükârâ" ("drunkards"). The second variant looks more plausible as an attributive for "kâfir", given the dim view of the Ottoman religious ideology regarding the use of alcohol in non-Muslim societies. See: N. Karaçay Türkal, Silahdar Fındıklılı Mehmed Ağa. Zeyl-i Fezleke (1065-22 Ca.1106 / 1654-7 Şubat 1695) (Tahlil ve Metin). Doktora Tezi [N. Karachay Turkal, Mehmed Aga Silahdar of Fyndykly. The Continuation of the Summary (1065-22 Ca. 1106 / 1654-7 February 1695) (The Analysis and the Text). PhD Thesis], Istanbul: Marmara University, 2012, p. 1034. 
weapons of war, take the sort [of salt] they desire according to the current market price ${ }^{50}$ and return; and thus was the answer written on his [envoy's] letter; and from Crimea through the Black Sea he went to his land. ${ }^{51}$

The depiction of the sultan's behavior and the legate's words in the History of Silahdar (Şikayet defteri, 1097-1098 touches this theme as well) convinces that its writer was well acquainted with the events of the Moscow legation. The fragment also gives us the date of Alekseyev's audience as April 14, 1686.

One of the most important nuances of this note is the irony of Mehmed IV with regard to the Moscow Tsars. His words "drunk infidel" may reflect the Ottomans attitude towards Muscovy at the end of the Xvirth century as obviously arrogant, clearly showing that the Ottomans would grant no concessions. The order of Mehmed IV given at the end of the audience confirms this as well: the release of forty slaves to Moscow is more of a symbolic gesture than a concession, given the Sultan's refusal to cede the salt deposit. The Sultan's orders and the legate's messages coincide with the records of the Şikayet defteri, 10971098.

The fragment according to $\mathrm{S}$. Ternovskij mentions neither a special request by the Muscovite legate regarding the Church nor the Grand Vizier Sary Suleiman Pasha ${ }^{52}$, who Alekseyev would have approached. Instead, Silahdar mentions in the previous charter that in March 1686 Grand Vizier was appointed as a main commander on the western front. ${ }^{53}$ On April 191686 he was given

50 It bears mention that the edition of the History of Silahdar mistakenly uses the word [nzkh?], non-existent in Ottoman Turkish Language. See James W. Redhouse, A Turkish and English Lexicon, Istanbul 2011, p. 2078. Instead of it, the word نر [nerkh] ("a market price as set by or taxed by authority"), which differs only by the absence of a single dot, gives a clear meaning to the last part of this passage. See Redhouse, Turkish, p. 2077.

سـلحدار فندقليلي محمد آغا lahdar], 2 vol., Istanbul: Orhaniye Matbaası, 1928, vol. II (1090-1106), p. 238.

$5^{2}$ Sary Suleiman Pasha (1627-1687), an important character of the events of 1686 , is a controversial figure in Ottoman history. During the reign of Mehmet IV, he rapidly climbed ranks, rising from confectioner in the Sultan's palace to Grand Vizier. He occupied from December 1685 to the end of September 1687, when an army mutiny following a defeat in the Battle of Mohacs against Austria brought his career to an end. In October 1687, the pasha was executed. Silahdar dismisses him as little more than a corrupt, scheming courtier; see سلحدار تاريخي ,سـلحدار, pp. 294-295. Conversely, J. Hammer-Purgstall describes him as a master of intrigue in both the Ottoman court and the international arena; see J. Hammer-Purgstall, Büyük Osmanlı Tarihi [History of the Ottoman Empire], 10 vol., Istanbul, 1994, vol. VI, pp. 427-452. 
sancak-i şerif54 and left for his commander's tent; as understood from the following chapter, four days later he departed to Belgrade. ${ }^{55}$ From mid-March until that date, the Grand Vizier had been occupied with preparing the military campaign. ${ }^{56}$ Did he have enough time to delve into the affairs of the Muscovite legation? The question needs to be answered.

Dionysius IV was elected as the Patriarch of Constantinople in March 1686. ${ }^{57}$ As S. Ternovskij states, at the time when legates met the Patriarch he had come to Edirne to have his appointment confirmed by the Sultan. ${ }^{58}$ According to N.F. Kapterev, Dionysius IV obtained this confirmation on April 7th 1686 (April 17th Gregorian calendar). The piskoposluk kalemi defterleri ${ }^{59}$ of the Divan contain a mention regarding the abolition of the peshkesh ${ }^{60}$ to the Patriarchs of Constantinople dated exactly on April 17, 1686.61 Thus, exactly at the time of Alekseyev's visit, the Patriarch of Constantinople obtained the privilege from the Ottomans. As a result, it seems unlikely that he would indulge in such antiOttoman intrigue as the transfer of the Metropolia of Kyiv.

54 Türkal, Silahdar, p. 1036.

55 سلحدار تاريخي رسلحدار, pp. 236, 249. Concerning the date of the departure of the grand vi-

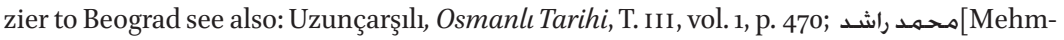
et Rashit], تاريخ راشد [History of Rashit], 6 vol., Istanbul, 1865, vol. I, p. 490.

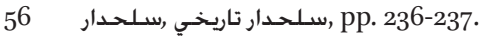

57 Seе Э.П.Г., “Дионисий IV Серогланис".

58 Соловьев, История, book 3, vol. xIV, p. 10о1; Терновский, "Исследование о подчинении", р. 142.

59 Piskoposluk kalemi defterleri are the registers of the episcopal affairs bureau of the Ottoman divan concerning ecclesiastic issues. See Osmanlı Arşivi Rehberi [Ottoman Archive Catalog], Istanbul, 2010, pp. 216-217, 337.

60 Peshkesh was a ceremonial present or a monetary sum, brought as a gift or offering by an Ottoman official to his superior. From 1466 to 1686, all Constantinople Patriarchs paid peshkesh to the Sultan in exchange for a berat, a patent that confirmed an appointment in the Ottoman Empire and delineated the bearer's responsibilities. See Elif Bayraktar Tellan, The Patriarch and the Sultan: The Struggle for Authority and the Quest for Order in the Eighteenth-Century Ottoman Empire. PhD Dissertation, Ankara, 2011, p. 20, 37.

61 Over the centuries, the peshkesh for Constantinople Patriarchs reached the 1 million akche (Ottoman silver piece). After 1686, the Patriarchs would pay for the equivalent of 100 okkas [ 1 okka equals $1.282 \mathrm{~kg}$ ] of meat daily to the hâssa bostâncılar ocağı (the Corps of Imperial Guards). The equivalent of 100 okkas of meat was 33,333 akches monthly, or 399,996 akche annually - a much smaller amount than before. See Tellan, The Patriarch, pp. 164 . 
Not only Ottoman sources but also J.F. Hammer-Purgstall's Geschichte des Osmanischen Reiches contradict the Russian depiction of the Muscovite legation. Hammer's mention of the 1686 legation is as follows: "In response to the mission of the latest chavush ${ }^{62}$ to Russia, the Russian legate came with a retinue of twenty people. He proposed to renew the capitulation on the condition that they (Russians) withdraw from the lands near Kyiv, and obtained a permission to rebuild the Greek church". ${ }^{63}$

Hammer cites the source of this information as the Italian chronicle Relazione di Constatinopoli:

c. And it so happened that the Muscovite legate came with twenty men: he claimed a fortress situated near Kyiv in the Turkish dominions and upon this had the capitulation confirmed. May 1686. Cod. 884 p.501. d. ${ }^{64}$

d. The Muscovite envoy enjoyed different honors and pleasures, and learned that the Franks had managed to have their church restored. Thus the Greeks asked the Muscovites to persuade the Porte to rebuild a church that had burned down many years ago, and that is how the Greeks got permission to rebuild their church of Saint John in Constantinople, near the Balata Port not far from the sea. In addition, the Sublime Porte gave to the Muscovites a part of Ukraine from Moscow to Uman ${ }^{65}$ so that the Cossacks would use it. Cod. 884.1686 p. 562 und $564 .{ }^{66}$

As understood from this fragment, the Moscow legation stayed in Edirne, vying to confirm the conditions of the 1681 Bakhchysarai Peace Treaty. Hammer's commentary and his notes in the original text are rather complicated; however, according to the original and its Turkish translation, it is clear that the Ottomans agreed to confirm the Bakhchysarai Treaty and rebuild the church of John the Baptist only if the Russians had withdrawn from the lands near Kyiv. The Muscovite legation did achieve the restoration of the Church of John the

62 Chavush is an official messenger, emissary, or sergeant.

63 Translated based on a comparison between Turkish and German editions of Hammer's work; some minor ambiguities exist in the original fragment. J. Hammer-Purgstall, Geschichte des osmanischen Reiches, 10 vol., Pest, 1830, vol. vi, p. 464; J. Hammer-Purgstall, Büyük Osmanlı Tarihi, vol. vi, p.426.

64 Hammer-Purgstall, Geschichte, p. 464.

65 Uman is a historical city in Central Ukraine.

66 Ibid. 
Baptist in the Balata district, as mentioned in S.M. Solovyov's History of Rus$s i a^{67}$. However, as understood from the Relazione di Constantinopoli, the mission of the legation did not involve the question of the Kyiv Metropolia. ${ }^{68}$

Hammer also reveals an important nuance. The Ottomans demanded from Moscow to forfeit the territories near Kyiv in order to confirm of the Peace Treaty. The historian, together with Silahdar and Şikayet defteri, 1097-1098, confirms that the Ottomans did not intend to make any serious concessions to Muscovy. This position of the Sublime Porte also coincides with its enticement of the population of the Left-Bank population to move to the Right Bank after ratification of the peace treaty. This policy obviously went against the conditions of the treaty but continued until the breakout of the Ottoman-Russian war of 1686-1700. ${ }^{69}$ The privileges bestowed on Left-Bank immigrants to Ottoman dominions are recorded in Şikayet defteri, 1097-1098, reaffirming the Ottoman hard line in relations with Muscovy all the way back in 1686 .

Therefore, the Relazione di Constantinopoli complements the Ottoman sources and reinforces their depiction of the negotiations with Muscovy. It makes no mention whatsoever of the Church-related mission of the Moscow legation. Another significant fact is that, contrary to Russian sources, the Italian chronicle claims that the legation was limited to thirteen persons. The congruence between Ottoman and Italian sources regarding the matter of the Kyiv Metropolia means that its transfer took place under unclear circumstances.

Ottoman historical sources on the 1686 Moscow legation to Edirne suggest important alterations to the claims of Russian histories. Three new sources analyzed in the article, however different their origins may be, do not contradict each other. The main differences between them and Russian narratives consist in the fact that they make no mention of the church question, supposedly the very basis of the Muscovite mission, instead concentrating on facts entirely absent from Russian narratives.

67 See Соловьев, История, book 3, vol. xIV, p. 1002; Z. Karaca [Z. Karadja], İstanbul'da Osmanlı Dönemi Rum Kiliseleri [Greek Churches of Ottoman Epoch in Istanbul], Istanbul, 2006, p.107.

68 Hammer's History... also mentions that, during the same period of Sary Suleiman Pasha's government, when Cossack legates arrived to the Sublime Porte, they would "come with letters and presents, be granted audience by the Sultan, treated and gifted with kaftans". See Hammer-Purgstall, Büyük Osmanlı Tarihi, vol. vi, pp. 428-429.

69 Чухліб, Козаки імонархи, pp. 303-31з. 
They mention the conditions of the Bakhchysarai Peace Treaty and their confirmation, Moscow's claims on the salt deposits near Crimea, the migration of the Left-Bank Ukrainian population to Ottoman domains, the liberation of the Ukrainian and Russian slaves, the rebuilding of the Church of John the Baptist in Balata, and other non-ecclesiastical questions. Contrary to S. Ternovskij and S.M. Solovyov, the fragments of Şikayet defteri, 1097-1098, the History of Silahdar and the Relazione di Constantinopoli demonstrate that the Ottomans did not bestow upon the Tsardom of Muscovy any concessions that would include the transfer of the Metropolia of Kyiv. The question of the number of Muscovite legates also raises new doubts concerning the Russian legation in the light of the Relazione di Constantinopoli. Moreover, important privileges obtained by the Patriarch of Constantinople from the Ottomans just before he signed his charters concerning the Metropolia give grounds for more doubt in the Russian narratives. It seems exceedingly unlikely that the Patriarch, a privileged member of the Ottoman administration ${ }^{70}$, would forfeit such an important instrument of Ottoman influence on the Cossack State as was his hierarchical dominance over the Metropolia of Kyiv, and would undertake such a drastic step without the consent of Ottomans, who were firmly indisposed towards any concessions to Muscovy. B. Lourié has already suggested the same theory, explained from the canonical viewpoint of the Orthodox Church. Confirmed by K. Vetoshnikov's research, the Greek charters of the Council discovered by V.G. Chentsova, and Ottoman sources, it gains a new relevance.

The problem must be extensively analyzed in the context of Ottoman religious life, a topic of many new recent works. Perhaps the loss of the traditional order of the Ukrainian Church can be explained by yet-unresearched sources. One such item are the registers of Posolskiy Prikaz for the years 1685 and 1686, concerning the legation of Nikita Alekseyev to Turkey ${ }^{71}$, recently discovered and only waiting to be published. ${ }^{72}$ Documents of Posolskiy Prikaz include the instructions of the Tsars to their legates and official reports

70 On the Ottoman administrative functions of the Patriarch of Constantinople and Patriarchs of Other Orthodox Churches as the heads of Christians and national minorities of the Ottoman Empire see: Tellan, The Patriarch; Hasan Cholak, The Orthodox Church in the Early Modern Middle East: Relations between the Ottoman Central Administration and the Patriarchates of Antioch, Jerusalem and Alexandria, Ankara, 2015; Salahi R. Sonyel, Minorities and The Destruction of The Ottoman Empire, Istanbul, 1993; J. Kabrda, Le Systeme Fiscal de L'Eglise Orthodoxe dans I'Empire Ottoman, Brno, 1969; Halil İnalcık, "The Status of the Greek Orthodox Patriarch under the Ottomans", Turcica, 21-23, 1991, pp. 407-435; Macit M. Kenanoğlu, Osmanlı Millet Sistemi: Mit ve Gerçek, İstanbul, 2004.

71 Rogozhın, "Rus Diplomatların".

72 At the time of writing, the authors were informed by Vera Chentsova that she was preparing the Registers of Moscow's Posolskiy Prikaz for the years 1685 and 1686 for publication. 
on diplomatic missions. ${ }^{73}$ At the same time, Ottoman archives require more thorough researches. It is also plausible that an analysis of the Ikona...manuscripts, mostly translated from the Greek, can aid in revealing some new nuances in the Church problem.

The distorted depiction of the 1686 Muscovite legation in Russian narratives can cast a shadow on an entire page of the Ukrainian and the Orthodox Church history. The search of the historical truth in this situation will aid in understanding the importance of the church factor for the Ottomans and reveal the base of Russian encroachment on Ukrainian Church territories. In addition, it can cast a light on the legitimacy of the Ukrainian Church's belonging to the Patriarchate of Moscow over the last three centuries.

73 Rogozhın, "Rus Diplomatların”. 


\section{Appendix 1. Fragment of «Şikayet defteri, 1097-1098»}

[s. 16/h. 54]

To the beylerbey ${ }^{74}$ of Özi $\left(\right.$ Eyalet $^{75}$ of Ochakiv $\left.{ }^{76}\right)$ Recep (Rejep) - may Allah prolong his bliss - and to the sanjak-bey ${ }^{77}$ of Doğangeçidi (Doangechidi) ${ }^{78}$ Ebubekir, and the sanjak-bey of Kylburun ${ }^{79}$ Mustafa - may Allah prolong his greatness - and to the mütesellims (myutesellims) ${ }^{80}$ of mirimiran ${ }^{81}$ and mirliva ${ }^{82}$, and to the posts of kethüda (kethyuda) ${ }^{83}$, and to the serdars [commanders] of the janissaries, and to the wardens of fortresses and palankas [forts] and citadels, and to the agas [commanders] of soldiers, and to the notables of vilayet, ${ }^{84}$ and to men of deeds and to Yani, the Ukrainian Hetman, - may Allah increase his obedience - the order is as follows:

It is written again that the Muscovite rayah and the Potkal Cossacks which live on the other bank of the Özi river [the Dnieper] may come to the bank of Özi where the border of conquests ends and which has become a place of maintenance for the spoils of our victorious overlord, and to the salt deposits near the Black Sea to earn their living, as long as they keep calm and bear no arms, as required by the ruled of good behavior on the far side; they may chop wood and keep beehives, mow grass on pastures and fish in yonder small rivers and lakes, and hunt in the steppes, buy as much salt as they need and be assured of their security; nobody may impede their arrival and departure in any way and charge them with tithes and dues; nowadays they who are accordingly to the request and privileges of the Moscow tsars joined and adhered to my ahidname- $i$

74 Beylerbey, general-governor or ruler of a beylerbeyilik, the largest administrative unit of the Ottoman Empire (starting in the Xvith century, the latter term was supplanted by eyalet).

75 Eyalet, the synonym of beylerbeyilik, was the first-order administrative division of the Ottoman Empire.

76 The Ottoman Özi is the contemporary Ochakiv, a city in Southern Ukraine.

77 Sanjak-bey, governor of sanjak, a province making part of an eyelet and divided into kazas, smaller administrative units.

78 Doğangeçidi ("Customs Criossing”), Tavan crossing, presently Beryslav in the Kherson Oblast (Southern Ukraine).

79 Kılburun ("Hairy Cape"), Kinburn promontory and the Ottoman fortress standing there (now in Southern Ukraine).

8o Mütesellim, a title referring to the head of a nahiye, an administrative unit smaller than a $k a z a$, or civil governors of towns tasked with tax collection and maintaining public order.

81 Mirimiran, synonymous with of beylerbey.

82 Mirliva or Mîr-i livâ is a high military rank of the Ottoman Army corresponding to Major General in modern armies. The word itself is compound of Mir ('commander' in Persian) and Liva ('brigade' in Arabic). Sanjak-beys also had the rank of mirliva.

83 Kethüda is an Ottoman Turkish title meaning "steward, deputy, lieutenant", found in both central and provincial administration.

84 Vilayet, synonymous with elayet, is a first-order administrative division, governorate or province in the latter-day Ottoman Empire. 
hümayun (ahidname-i hyumayun) ${ }^{85}$ may know the power of my name-i hümayun; ${ }^{86}$ so that my ahidname-i hümayun may be implemented properly, let Cossacks possessing a charter from the otaman $^{87}$ or the hetman of the Potkal Cossacks not be impeded in their arrival to salt deposits and fortresses in order to buy salt; however, let no outlander or Cossack brigand sneak in under the pretext of buying salt with no papers; and let all slaves be set free - regardless whose property they are - who are still infidels and have not converted to Islam and who had been captured after the Peace Treaty contrary to my Sultan's will; and hence in defiance of my ahidname-i hümayun settlements of the reaya, subjects of the Muscovite land, may not be burned, they may not be slaved and attacked and treated as enemies.

Last decade of Jumada al-Akhira, year $1097^{88}$

[s. 16/h. 55]

To the sanjak-bey of Azak ${ }^{89}$ Timurshah - may Allah prolong his greatness - the order is:

After it had become known that up to this moment, in defiance of my ahidnamei hümayun and disrupting peace and stability, numerous attacks and hostile actions had been undertaken, against Muscovy and the reaya of palankas near Azak, which lies within Muslim dominions, you were interrogated and reprimanded. It is written that if they are calm and bear no arms, they may safely and surely arrive for in order to make a living, and no one may impede their coming and going; and release the slaves belonging to Muscovy and the population of palankas - no matter their master - who are still infidels and have not converted to Islam and who have been captured in defiance of ahidname-i hümayun and the calm and stability tat followed the Peace treaty, and afterwards let no attacks and hostilities [towards Muscovy and the reaya of palankas] come to pass.

The last decade of Jumada al-Akhira, 1097

85 An official agreement between the Sultan and a sovereign ruler of another country, Muslim or not. The Sultan strengthened such agreements by taking an oath. Hümayun (hyumayun), a word of Persian origin, means imperial.

86 Letter of the sultan, imperial letter.

87 Title of the Cossack commander.

88 May 14-23, 1686.

89 Azak, former fortress of the Ottoman Empire, nowadays known as Azov, a seaside town in the Rostov Oblast of the Russian Federation. 
[s. 16/h. 56]

To the kaymakam ${ }^{90}$ of Istanbul the order is:

(...) it is written for you to deliver to the man sent by the Hetman of Potkal Cossacks the following twenty-two freed Cossack slaves, captured during the conquest and till now kept in Tersane-i Amire, their names being: Mihal Domasoski and Sinolmak and Vasili Yuri and Stefan Teodori Kolomaski and Avrilir Jaliskov and Yivan Maslovidj and Vasili (...) Lantselott and Semire Maridjmer Skala and Kuzma Mazkali and Vasili (...) and Vasili Kravcha Kurick and bany Malnichokof and Stefal bany Niko and Semiraseric (...) and Vasil Poul (...) and Maksim Bolan (...) Trobolaski and Niko and (...) Maturicki.

Same date.

[s. 17/h. 57]

To the kaymakam of Istanbul the order is:

It is written to free and deliver to the legate who came from the Muscovite tsars the following ten freed Muscovite slaves, captured (...) during the conquest and till now kept in Tersane-i Amire, , their names being: Mihail, the son of Andon, and Kuzma(?), the son of İvan, the son of (...), the son of (...), Sem? İvan and Kirkor, the son of (...), son of (...) and Mihail, the son of Stefan (...), Mihail and (...), the son of Hristo (...), Andon (...).

The last decade of Jumada al-Akhira, 1097

[s. $17 /$ h. $\left.5^{8}\right]$

To the kaymakam of Istanbul the order is:

It is written, as required by the Sharia Law and following an intercession by the legate Nekta Alekseyevich, to immediately remove those Moscow slaves who are now in Istanbul and are still infidels and have not converted to Islam from the place where they had been set free, as they had been captured in defiance of my ahidname-i hümayun,

Last decade of Jumada al-Akhira, 1097

9o Kaymakam. deputy or placeholder for the Grand Vizier during the latter's illness or absence from the capital on a campaign or for other reasons. 
[s. 17/h. 59]

To the kaymakam and kadi ${ }^{91}$ of Istanbul the order is:

It is written that no one dare impede the departure of Muscovite and Potkal Cossack slaves, who desire to come back to their lands and had been enslaved long ago and, following the precepts of Sharia Law, are released as infidels without having converted to Islam, together with Nekta Alekseyevich and the man sent by the Hetman of Potkal Cossacks.

The last decade of Jumada al-Akhira, 1097

[s. 17/h. 6o]

To the sanjak-bey of Kylburun, Mustafa, - may Allah prolong his greatness - the order is:

It is written that when the legate Nekta Alekseyevich, who had come to the Sublime Porte from the Moscow tsars, and the man sent by the Hetman of Barabash Cossacks are deemed worthy of the Sultan's permission for their return, you must, on arrival to the other side. take an obligation to meet him with the necessary number of people, and to release, send, and deliver them to their respective lands from the place known to them.

The last decade of Jumada al-Akhira, 1097

[s. 17/h. 61]

According to the law, the following order is written regarding the return of the Muscovite legate for the following officials: the kadis and the myutesellims of mirmiran and mirliva and the kethyudas and the serdars of the Janissary Corps, and the wardens of fortresses, and the agas of soldiers, and the notables of vilayet, and other men of deeds who may be encountered as he travels from Edirne to Istanbul; from there he is to leave via the Black Sea to Özi (Ochakiv), and from there to the Muscovire border.

Last decade of Jumada al-Akhira, 1097

[s. 17/h.62]

It is also written that the same must be done for the man of the Barabash Hetman as he travels from Edirne to Istanbul and from there via the Black Sea to Özi and from there to the Potkal Island. Same date. ${ }^{92}$

Şikayet Defteri 1097/1098 [Register of Complaints 1097/1098], Istanbul, pp. 16-17.

$91 \quad$ Kadi is a judge of the Sharia court.

92 Demir, 1686-1687 (h. 1097-1098) Tarihli, pp.188-191; A. DVNs. Şкт.d. o10, Şikayet Defteri 1097/1098 [Register of Complaints 1097/1098], T.C. Başbakanlık Osmanlı Milli Arşivi [Turkish Republic, the Prime Minister's Ottoman Archive], Istanbul, pp. 16-17. 